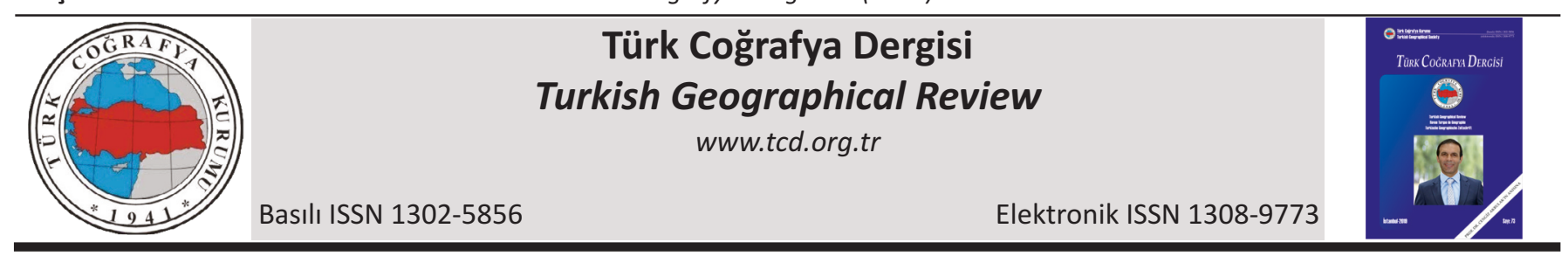

\title{
Üniversite öğrencilerinin kent imajlarına yönelik bir araştırma: Siirt Üniversitesi örneği
}

\section{An investigation on the perspectives of the university students on city image: the case of Siirt University}

\author{
Adnan Alkan*a (1) Semra Yılmaz Çildamª \\ ${ }^{a}$ Siirt Üniversitesi, Fen-Edebiyat Fakültesi, Coğrafya Bölümü, Siirt.
}

\section{BILGi / INFO}

Geliş/Received: 06.08.2019

Kabul/Accepted: 22.12.2019

\section{Anahtar Kelimeler:}

Siirt

Kent

İmaj

Üniversite

Öğrenci

\section{Keywords:}

Siirt

City

Image

University

Student

*Sorumlu yazar/Corresponding author:

(A. Alkan) ad_alkan@hotmail.com

DOI: $10.17211 /$ tcd.602568

\section{Atrf/Citation:}

Alkan, A., Çildam, Y. S. (2019).Üniversite öğrencilerinin kent imajlarına yönelik bir araştırma: Siirt Üniversitesi örneği. Türk Coğrafya Dergisi (73), 90-95 DOI:10.17211/tcd.602568

\begin{abstract}
ÖZ / ABSTRACT
Beşeri coğrafi görünümün önemli bir parçası olan kentler, içinde yaşayanlar tarafindan farklı şekillerde algılanmaktadır. Kent imajı insanların deneyimi sonucu ortaya çıkmaktadır. Bu deneyim kentle ilgili inançlar, fikirler ve izlenimler üzerinde oldukça etkilidir. Algının kentsel mekânın anlaşılması, organize edilmesi ve bir takım problemlerinin çözümünde önemli bir yeri vardır. Öte yandan kentlerin eksikliklerini gidermek, olumsuz taraflarını düzeltmek ve kentte farkındalığı artırmak için öğrencilerin kentsel değerlendirme imajı bilinmelidir. Bu çalışmada; Siirt Üniversitesi'nde eğitim gören öğrencilerin perspektifinden, Siirt kenti imajına ilişkin algılarının ölçülmesi amaçlanmıştır. Çalışmanın temelini Siirt Üniversitesi öğrencilerinin Siirt kentini nasıl algıladıkları ve öğrencilerin bakışına göre kent imajının nasıl olduğu oluşturmaktadır. Bu kapsamda Siirt Üniversitesi'nin lisans ve ön lisans bölümlerinin son sınıflarında okuyan 380 öğrenciye anket uygulanmıştır. Anket çalışmasıyla birlikte; üniversite öğrencilerinin perspektifinden, kentin üstünlük imajları, kentin soyut imajları ve kent halkına yönelik imajlar tespit edilmiştir. Katılımcıların tümü birlikte değerlendirildiğinde; iklim ve lezzetli yemekler yüksek imaja sahip ifadelerdir. Yeşil alan, sanatsal etkinlikler, konaklama imkânları, sportif ve kültürel faaliyetler, alışveriş olanakları, sanayi ve ekonomik koşullar ile ilgili katılımcı imajları da düşük olduğu anlaşılmıştır. Katılımcıların Siirt'i sakin ve az gelişmiş bir kent olarak algıladıkları gözlenmektedir. Ayrıca Siirt Üniversitesi öğrencileri, Siirt halkını dindar, gelenekçi ve sıkıcı olarak ifade etmektedir. Sonuç olarak katılımcıların Siirt kent imajlarının düşük olduğu anlaşılmaktadır. Üniversite öğrencileri, kent halkının kendilerini benimsemediklerini, dolayısıyla kent ile bütünleşemediklerini belirtmişlerdir.
\end{abstract}

Cities, which are an important part of man-made geographical appearance, are perceived differently by their inhabitants. The image of the city is the result of people's experience. This experience determines beliefs, ideas and impressions about the city. Perception is important in understanding, organizing and solving various problems in the urban localities. On the other hand, perception of students on urban localities should be identified in order to meet needs of the city, correct its negative aspects and increase diversity of the cities. The objective of this study was to determine the perception of the city of Siirt by the students studying at the Siirt University. Determining perception of the city of Siirt by the Siirt University students and how they perceive the city image constitutes the basis of the study. In this context, a questionnaire was sent to 380 students who were in their last year of undergraduate and associate degrees in the departments of Siirt University. Along with the survey, perception of superiority of the city, abstract images of the city and perception of its residents from the university students' perspective were also determined. When all participants were evaluated in totality, the climate and the delicious foods were expressions carrying high importance. It was also found that the participants' perceptions regarding green environment, artistic activities, accommodation facilities, sports and cultural activities, shopping opportunities, and participation in industrial and economic conditions carried lower importance. It is observed that the participants perceive Siirt as a quiet and underdeveloped city. In addition, Siirt University students describe the people of Siirt as religious, traditional and boring. As a result, it is understood that the city images of the participants in Siirt are low. University students stated that the people of the city did not adopt themselves and therefore could not integrate with the city.

\section{Giriş}

Kentler, farklı kural ve kurumlara sahip, çevresiyle etkileşim halinde ve çevresine çeşitli hizmetler sunan, seçeneklerin bol, fir- satların çok olduğu, karmaşık ve yoğun ilişki ağlarının gerçekleştiği merkezi yerleşmelerdir (Aliağaoğlu ve Uğur, 2016). Kentlerin kendilerine özgü süreçleri ve toplumsal dinamikleri, onların mekânsal yapılarının şekillenmesinde onlara öncü bir rol yükler (Ataöv ve Osmay, 2007). Günümüzde kentlerin geliş- 
mesinde ve mekânsal büyüme gerçekleştirmelerinde, dışarıdan kaynak sağlayacak çekiciliklere sahip olmaları son derece önemlidir. Doğal, beşeri ve ekonomik çekiciliklerin yanında kentlerin imajı ve pazarlama değeri gibi hususlar da son yıllarda kentlerin gelişmesinde etkili bir faktör olmuştur.

Günümüzde kentler farklılıklarını ön plana çıkararak özgün olma eğilimindedirler. Bu özgün olma hali kent imajını doğurmaktadır (Demirel, 2014). Kentler için önem arz eden imaj kavramı, kentte yaşayanların izlenim ve tutumlarının bileşkesinden oluşmaktadır. Kentler orada yaşayanlar tarafindan aynı düzeyde algılanmazlar. Oluşan kent algısı, mekânı anlamada, aksaklıkları tespit etmede yol gösterici olabilmektedir. Kentsel imaj, kentsel fonksiyonlar, kent içi arazi kullanımı başta olmak üzere birçok faktörü etkilemektedir. Kentin doğru algılanması verilen kent imajına bağlıdır. Kent algısı kentsel faaliyetler, kentin dış görünüşü, halkın tutum ve davranışları, benzer kentlerle girdiği rekabet ortamına göre şekil almaktadır (Aliağaoğlu ve Uzun, 2017).

Dijital çağa geçiş yapılan bu dönemde her şey gibi insan hareketliliği de artmıştır. Hareketli nüfus tatil, iş, kongre, eğitim vb. nedenlerle kentleri ziyaret etmektedir. Dolayısıyla kentler, içinde barındırdığı tüm değerleri ile esasında bir pazarlama ürünüdür. Bu ürünün doğru pazarlanması kentteki tüm paydaşların sosyo-ekonomik gelişimine önemli bir katkı sunacaktır (Özdemir ve Karaca, 2010).

Her kent kendine has olduğu için kentler ile ilgili imaj algısı da birbirinden farklı olacaktır. Nitekim bugünün dünyasında kentler arası rekabette kentlerin imajı bu rekabette ön plana geçmede önemli bir belirleyicidir. Çünkü oluşan kent imajı ile kişi o kent ile bağlarını ya kuvvetlendirir ya da zayıflatır (Antholt, 2006). Kent ile kuvvetlenen bağlar kişiyi o kente yerleşmeye kadar götürebilir. Dolayısıyla olumlu bir imaj ile kimlik kazanan kent gerek ekonomik yönden gerekse sosyo-kültürel anlamda kazançlı çıkacaktır (Cop ve Akpınar, 2014).

Bu çalışmanın konusunu üniversite öğrencilerine göre kent imajı oluşturmaktadır. Çalışmada Siirt Üniversitesi öğrencilerinin Siirt algısı ve zihinlerinde oluşturdukları kente ait izlenimleri yani kent imajı ölçülmeye çalışılmıştır.

Kentlerin aksayan kısımlarını tespit etmek, zayıf yönlerini bertaraf edip güçlü yönlerini ön plana çıkarmak ve kendine özgü değerleriyle farkındalık yaratmak için güçlü bir kent imajı gerekmektedir (Aliağaoğlu ve Uzun, 2016). Bu kapsamda çalışmada Siirt Üniversitesi öğrencilerinin kent imaj algısı ve bunun oluşumuna neden olan faktörlerin ölçülmesi amaçlanmıştır. Bu doğrultuda öğrencilerin Siirt kentinin üstünlüklerine yönelik imajları, Siirt kentinin soyut imaj unsurlarına yönelik tutumları, Siirt halkına yönelik tutumları, cinsiyete göre Siirt imajı ve Siirt kent imajı algılarının Siirtli olup olmamalarına göre değişkenliği gibi konularda imaj algıları araştırılmıştır. Bu şekilde Siirt Üniversitesi öğrencilerinin kentsel imaj algısı ortaya konmuştur.

\section{Kentler İçin İmajın Önemi ve Üniversite Öğrencileri- nin Kent İmajı Üzerine Etkisi}

Coğrafya öteden beri, insan ve mekân ilişkilerini değerlendirmede çoklu bir bakış açısına sahiptir. Davranışsal coğrafya ve çevresel algı da şüphesiz bu bakış açıları arasında en önemlilerinden biridir (Karadağ ve Turut, 2013). Davranışsal coğrafya, insanların farklı özelliklere sahip çevre birimlerini nasıl algıladıklarını, hangi sembollerle tanımladıklarını, bu tanımları ne tür şekillerle ifade ettiklerini ve bu çevrelere verdikleri tepkileri ele alan bir yaklaşımdır. Bu nedenle insan davranışlarının temelinde yaşadığı çevrenin bir etkisi varsa, insan çevre ilişkileri konusuna odaklanmış bir bilim olan coğrafya için de "çevresel algı" şüphesiz ki temel araştırma konusudur (Özgüç ve Tümertekin, 2007). Bu bağlamda insanların çevresel algılarının oluşmasında kentlerin ve içerisinde bulundukları çevrenin doğal ve beşeri çevreye ilişkin tüm bileşenlerinin belirleyici olduğunu vurgulayan Lynch'in kentsel çevre algısı ve imajı konusundaki çalışması bu alandaki ilklerdendir (Lynch, 1960).

Kentin nasıl algılandığı sorusuna verilen cevap, kentsel imajı tanımlamaktan başka bir şey değildir. Bir kentin zihinde bıraktı̆ı izlenimler, resimler toplumsal belleğin, ortak hafizanın oluşmasında oldukça önemlidir (Türkan, 2017). Kentsel imaj; kişinin kentle ilgili duygu ve düşüncelerinin çıktısıdır. Başka bir deyişle kentle ilgili mevcut grubun zihinsel düşüncelerinin tümü olarak da görülebilir (Gecikli, 2012; Anholt, 2010).

Insanlar kentleri hatırlarken onları zihinlerinde kalan imajları yardımıyla anımsarlar (İri vd., 2011). Bu nedenle kentler için imaj kavramı oldukça önemlidir. Ayrıca iş, tatil, seyahat, yerleşme vb. birçok aktivite konusunda karar verme aşamasında da kentin imajı etkili olmaktadır (Özdemir ve Karaca, 2009). Doğrudan deneyimler, arkadaşlardan alınan bilgiler, kulaktan dolma bilgiler, gazete ve televizyon gibi görsel yazılı kaynaklardan edinilen izlenimler neticesinde insanların zihninde kent ile ilgili olumlu ya da olumsuz yargılar oluşmaktadır. Bu da kentlerin çeşitli amaçlar için tercih edilmesinde önemli bir etken olabilmektedir.

Kentte yaşayanların kentin pazarlama ve marka çalışmalarına katılımının kentteki doğal ve turistik değerlerin artmasına, hizmet kalitesinin yükselmesine, iş imkânlarının artmasına, temel ihtiyaçların daha iyi karşılanmasına bağlı olduğu unutulmamaIıdır. (Güler ve Gürer, 2015). Bu bakımdan kente üniversite öğrenimi amacıyla gelen üniversite öğrencilerinin kente yönelik algılarının öğrenilmesi son derece önemlidir. Zira üniversite öğrencilerinin farklı kentlerden gelmeleri kentte yaşayanlara göre o kent hakkında daha özgün değerlendirme yapmalarını sağlar ve bu anlamda kente yönelik değerlendirmeleri yaşayana kıyasla daha önemlidir. Ayrıca eğitim düzeyleri ve kente yönelik duygusal bağlılıklarının görece daha az olduğu düşünüldüğünde kente yönelik değerlendirmelerinin önemi artmaktadır (Gümüş, 2017).

Kentlerin en önemli bileşenlerinden olan üniversitelerin kente katkıları saymakla bitmez. Bunlar arasında ülkeye, bölgeye ve kente nitelikli işgücü kazandırmak, eğitimli, donanımlı, çağın gerekliliklerini yerine getirebilen tutarlı nesiller yetiştirerek toplumsal öncülük görevini yerine getirmek, bilgi üretmek, toplumu yönlendirmek, bilimsel çalışmalara ve aktivitelere öncülük etmek sayılabilir. Bütün bunların yanında üniversiteler, yerel ürün ve hizmetleri üreterek, pazarlayarak istihdam ortamı yaratarak ve kentin sosyo-kültürel yapısının gelişmesi anlamında da kente katkı sunmaktadır. Üniversitelerin kurulması ile kente nitelikli insan akışı (Öğretim üyesi, öğretim görevlileri, idari personel vb.) söz konusu olmaktadır. Farklı yöre, bölge ve ülkeden gelen genç ve dinamik öğrenci topluluğu geniş bir kültürel mozaik oluşturmaktadır (Özdemir ve Karaca, 2009). Ancak üniversiteye gelerek kentte uzun süre kalan öğrencilerin kenti diğer 
insanlara nasıl tanıttğı ve zihinlerindeki kent imajı son derece önemlidir. Zira bu imajın olumsuz olması halinde kentin sosyoekonomik durumunun da bundan etkilendiği ve diğer kentlerle rekabette geri kalmalarına yol açtığı anlaşılmaktadır.

\section{Materyal ve Yöntem}

Çalışmanın konusunu oluşturan Siirt Üniversitesi'nde 20182019 eğitim-öğretim yılı istatistiklerine göre 15.353 öğrenci öğrenim görmektedir. Bu öğrencilerin 8.672'si erkek, 6.665'i kız öğrencilerden oluşmaktadır. Çalışmanın evreni Siirt Üniversitesi Kezer Kampüsü, Merkez Kampüsü ve Sağlık Bilimleri Kampüsü’nde yer alan 8 fakülte (íktisadi ve İdari Bilimler, Güzel Sanatlar ve Tasarım, İlahiyat, Veteriner, Ziraat, Mühendislik, Eğitim, Fen-Edebiyat), 3 yüksekokul (Beden Eğitimi ve Spor, Yabancı Diller, Sağlık), 3 meslek yüksekokulunda (Sağlık Hizmetleri, Teknik Bilimler, Sosyal Bilimler) öğrenim gören öğrenciler oluşturmaktadır. Söz konusu birimlerde öğrenim gören 13.705 öğrenci bulunmaktadır. Araştırmanın örneklemi ise uygulanan ankete gönüllü olarak katılmayı kabul eden 380 öğrenciden oluşmaktadır. Ankete katılan öğrenciler bütün fakülte ve yüksekokuldaki bölüm ve programları temsil edilebilecek oranda rastgele seçilmiştir (Tablo 1).

Tablo 1: Ankete katılan öğrencilerin fakültelere göre oranları. Table 1: Proportion of the students who participated in the survey by faculties.

\begin{tabular}{|l|c|}
\hline Fakülteler & \%'si \\
\hline Egitim & 15,0 \\
\hline Fen-Edebiyat & 10,1 \\
\hline Ilahiyat & 9,3 \\
\hline Iktisadi ve Idari Bilimler & 5,1 \\
\hline Muhendislik & 3,7 \\
\hline Veteriner & 2,0 \\
\hline Ziraat & 1,9 \\
\hline Güzel Sanatlar ve Tasarum & 0,6 \\
\hline Yüksekokullar & \\
\hline Saglık & 6,5 \\
\hline Beden Egitimi & 5,8 \\
\hline Yabancı Diller & 1,4 \\
\hline Meslek Yüksekokulları & \\
\hline Sosyal Bilimler & 11,5 \\
\hline Sağlı Hizmetleri & 10,0 \\
\hline Teknik Bilimler & $\mathbf{7 , 2}$ \\
\hline Toplam & $\mathbf{1 0 0 , 0}$ \\
\hline
\end{tabular}

\subsection{Araştırmanın Veri Toplama Yöntemi}

Araştırmada "Siirt Üniversitesi Öğrencilerinin Siirt Kenti İle İlgili İmaj Algılamaları Araştırma Veri Toplama Formu" kullanılmıştır. Çalışmada kullanılan Veri Toplama Formu'nun oluşturulmasında, Özdemir ve Karaca tarafindan yapılan “ Kent Markası ve Marka İmajının Ölçümü: Afyonkarahisar Kenti İmajı Üzerine Bir Araştırma” isimli çalışma ile Aliağaoğlu ve Uzun'un "Üniversite Öğrencilerinin Kent İmajlarına Yönelik Bir araştırma" adlı çalışmada kullanılan ölçeklerden yararlanılmıştır. (Özdemir ve Karaca, 2009; Aliağaoğlu ve Uzun, 2017). Çalışmada kullanılan veri toplama formu dört kısımdan oluşmaktadır. İlk bölüm öğrencilerin demografik niteliklerini tespit etmeye yönelik sorulardan oluşmaktadır. İkinci bölümde kentin sahip olduğu avantajları tespit etmeye yönelik sorulara yer verilmiştir. Üçüncü bölümde kentin soyut imajını ölçmeye dair sorular sorulmuştur. Dördüncü kısımda ise katılımcıların kent halkına yönelik imaj algısını tespit etmeye yönelik sorulara yer verilmiştir. Veri toplama formunda öğrencilerin demografik özelliklerini tespit etmeye yönelik sorularda muhtelif seçenekler sunulmuştur. Diğer bölümlerdeki değişkenlerle ilgili sorularda beşli likert tipi (Geçikli, 2012) ölçek kullanılmıştır. (1. Tamamen katılmıyorum 2. Katılmıyorum 3. Kararsızım 4. Katılıyorum 5. Tamamen katlıyorum). Ayrıca anketin güvenirliliğini sağlamak için evrenini oluşturan gruptaki orana göre yeterli sayıda kız ve erkek katılımcıya anket uygulanmıştır.

\subsection{Araştırmanın Sınırlılıkları}

Çalışma, 2018-2019 eğitim-öğretim yılında Siirt Üniversitesi yerleşkelerinde yer alan 8 Fakülte (İktisadi ve İdari Bilimler, Güzel Sanatlar ve Tasarım, İlahiyat, Veteriner, Ziraat, Mühendislik, Eğitim, Fen-Edebiyat), 3 yüksekokul (Beden Eğitimi ve Spor, Yabancı Diller, Sağlık), 3 meslek yüksekokulunda (Sağlık Hizmetleri, Teknik Bilimler, Sosyal Bilimler) eğitim gören ön lisans ve lisans öğrencilerinin görüşleri ile sınırlıdır. Yüksek lisans ve doktora öğrencileri, pedagojik formasyon eğitimi alan öğrenciler ile lisans düzeyinde 1. 2. 3. Sınıf öğrencileri, ön lisans düzeyinde 1. Sınıf öğrencileri kapsam dışı tutulmuştur. Ayrıca Eruh ve Kurtalan meslek yüksekokullarında öğrenim gören öğrenciler de kent ile ilgili algı düzeyleri düşük olacağı düşünüldüğü için kapsam dışı bırakılmıştır. Araştırmada veri toplama süreci 01/02/2019-31/03/2019 dönemini kapsamaktadır.

\subsection{Verilerin Analizi Yöntemi}

Çalışmada elde edilen verilerin değerlendirilmesinde SPSS for Windows 16.0 (Statistical Program For Social Science) paket programından yararlanılmıştır. Araştırmada, öğrencilerin kent ve kent halkına yönelik imaj algılarının düzeyini saptamak için aritmetik ortalamaya bakılmıştı. Aritmetik ortalamalar yorumlanırken aralıklar;

$1,0 \leq$ ? $<1,8$ ise katılımcıların o imaja ilişkin algılarının çok olumsuz (Oldukça Düşük).

$1,8 \leq ?<2,6$ ise katılımcıların o imaja ilişkin algılarının olumsuz (Düşük).

$2,6 \leq$ ? $<3,4$ ise katılımcıların o imaja ilişkin algılarının kararsız (Orta).

$3,4 \leq ?<4,2$ ise katılımcıların o imaja ilişkin algılarının olumlu (Yüksek).

$4,2 \leq ?<5,0$ ise katılımcıların o imaja ilişkin algılarının çok olumlu (Oldukça Yüksek) olduğu şeklinde değerlendirilmiştir (Demirel, 2014:234).

\section{Bulgular}

Çalışmada üniversite öğrencileri tarafindan kent üstünlük imajları, kent soyut imajları ve kent halkına yönelik imajlar bir araya getirilerek Siirt kentinin genel imajı hakkında bilgi edinilmeye çalışılmıştır. Bu kapsamda ankete dâhil olan katılımcıların verdikleri cevaplar güvenilirlik açısından dikkate alındığında Cronbach's Alpha değerinin kabul edilebilir değer aralığında olduğu 
görülmektedir (Tablo 2). Ölçekte kent üstünlüğüne yönelik Cronbach's Alpha değeri 0,903 iken, kent soyut imajı değeri 0,801 ve halk imajı 0,930'dur. Bu değerler dikkate alındığında uygulanan ölçeğin yüksek bir güvenirliğe sahip olduğu görülmektedir.

Tablo 2: Imajlara ilişkin cronbahc's değerleri.

Table 2: Cronbahc's values regarding images.

\begin{tabular}{|c|c|}
\hline Imaj Grupları & Cronbach's Alpha \\
\hline Kent Óstlunluk & 0,903 \\
\hline Kent Soyut Imaj & 0,801 \\
\hline Halk Imaji & 0,930 \\
\hline
\end{tabular}

Katılımcıların cinsiyetlerine göre Siirt kenti imajına ait elde edilen tanımlayıcı istatistikler Tablo 3'te verilmiştir. Bu tabloya göre katılımcıların üç farklı açıdan ele alınan kent hakkındaki genel imajları onların cinsiyetlerine göre anlamlı bir farklılık arz etmemektedir (Tablo 3 ve 4).

Tablo 3: Katılımcıların cinsiyetlerine göre Siirt kenti imajı. Table 3: Image of Siirt City by gender of participants.

\begin{tabular}{|l|c|c|c|c|}
\hline & Cinsiyet & N & Std. Sapma & Std. Hata \\
\hline \multirow{2}{*}{ Kent Ưstünluk } & Erkek & 206 & 1,07057 & 0,07459 \\
\cline { 2 - 5 } & Kadın & 172 & 0,098617 & 0,07519 \\
\hline \multirow{3}{*}{ Kent Soyut Imaj } & Erkek & 206 & 0,87222 & 0,06077 \\
\cline { 2 - 5 } & Kadın & 174 & 0,82748 & 0,06273 \\
\hline Halk Imaji & Erkek & 206 & 1,07057 & 0,07459 \\
\cline { 2 - 5 } & Kadın & 174 & 0,98617 & 0,07519 \\
\hline
\end{tabular}

"Ōlçekte "1" kesinlikle katılmuyorum ve " 5 " kesinlikle katilıyorum anlamundadır.

Ankette uygulanan Kolmogorov-Smirnov normallik testi sonucuna göre Kent Soyut İmajı, Kent Halkı İmajı ve Kent Üstünlük İmajı ölçeklerinin normal dağılım göstermediği sonucuna varılmıştır. Normal dağılım göstermeyen veriler için geliştirilen bağımsız gruplar arasındaki farkın önemlilik testi olan Mann-Whitney U testi sonucu Tablo 4'te verilmiştir. Burada katılımcıların cinsiyetlerine göre yukarıda adı geçen ölçeklere verdikleri puanlarda bir farklııı olmadığı tespit edilmiştir.

Tablo 4: Katlımcıların cinsiyetlerine göre Siirt kent imajı. Table 4: Siirt City image by garticipants' gender.

\begin{tabular}{|c|c|c|c|c|c|c|}
\hline \multirow{3}{*}{ Siirt Kent İmajı } & \multicolumn{4}{|c|}{ Cinsiyet } & \multirow{2}{*}{\multicolumn{2}{|c|}{ Mann Whitney $U$ Testi }} \\
\hline & \multicolumn{2}{|c|}{$\begin{array}{c}\text { Kadun } \\
(\mathrm{a}-174)\end{array}$} & \multicolumn{2}{|c|}{$\begin{array}{c}\text { Erkek } \\
(\mathrm{a}-206)\end{array}$} & & \\
\hline & Ort. & S.S. & Ort. & S.S. & $\mathbf{z}$ & $\mathrm{p}$ \\
\hline Kent Soyut Imajı & 2.79 & 0.83 & 2.89 & 0.87 & -1.267 & .205 \\
\hline Kent Halks Imaji & 3.26 & 0.99 & 3.32 & 1.07 & .622 & .534 \\
\hline Kent Óst Imaji & 3.26 & 0.99 & 3.32 & 1.07 & -1.774 & .076 \\
\hline
\end{tabular}

"Ölçekte "1" kesinlikle katulmyorum ve " 5 " kesinlikle katllyorum anlamindadır.

Öte yandan kent üstünlük imajını ölçmek için yöneltilen sorularda, katılımcıların Siirt kentinin üstünlüklerine yönelik algılarında "iklimi uygundur" ve "Yemekleri lezzetlidir" ifadelerinin en yüksek imaj algılarını oluşturdukları anlaşılmaktadır. (Tablo 5).

Siirt'te karasal iklim şartları hüküm sürmekte olup dört mevsim en belirgin özellikleriyle görülmektedir. Yörede kuzeye doğru gidildikçe kışlar sert geçerken, güneye inildikçe daha ılıman kış şartları hüküm sürmektedir. Sahada yazlar da sıcak ve kuraktır. Birçok Mezopotamya uygarlığından etkilenmiş bir kent olan
Siirt, Güneydoğu'nun lezzet başkentlerinden biri konumundadır. Kentte birbirinden lezzetli çeşitli yöresel yemekler ve tatlılar mevcuttur. Büryan kebabı, perde pilavı, Siirt Kitel, Zerfet, Bumbar-Mumbar, Mihr Çorbası, Pırtke çorbası, Siirt Dolması namı diğer Arap dolması, Gebole, İmçerket gibi lezzetler sayılabilir. Bu faktörler, Siirt kentini gerek klimatik, gerekse gastronomik açıdan çekici kılarak olumlu bir algının gelişmesini sağlamaktadır.

Tablo 5: Katlımcıların Siirt kentinin üstünlüklerine yönelik imaj algıları.

Table 5: Participants' perceptions of image superiority of Siirt city.

\begin{tabular}{|c|c|c|c|c|c|c|}
\hline & $\mathrm{N}$ & Minimum & Maximum & Mean & Std. Deviation & Imai Alg Düzeyi \\
\hline Planli gelişmiştir & 379 & 1 & 5 & 2,39 & 1,260 & Daşak \\
\hline Itklimi uygundur & 380 & 1 & 5 & 3,49 & 1,313 & Yuksek \\
\hline Șehirlerarası ulaşum gelişsmiştir & 380 & 1 & 5 & 2,76 & 1,356 & Orta \\
\hline Yeșil alan yeterlidir & 380 & 1 & 5 & 2,32 & 1,294 & Düşak \\
\hline Kent içi ulaşım kolaydır & 380 & 1 & 5 & 3,37 & 1,429 & Orta \\
\hline Yemek lezzetlidir & 380 & 1 & 5 & 3,47 & 1,475 & Yuksek \\
\hline Eg̣itim imkânları iyidir & 380 & 1 & 5 & 2,63 & 1,274 & Orta \\
\hline Sanatsal etkinlikleri çoktur & 379 & 1 & 5 & 2,03 & 1,189 & Dessâk \\
\hline Konaklama imkânlan iyidir & 380 & 1 & 5 & 2,54 & 1,284 & Düşûk \\
\hline Spor etkinlikleri yeterlidir & 380 & 1 & 5 & 2,17 & 1,218 & Düșâk \\
\hline Doğal güzellikleri çoktur & 380 & 1 & 5 & 3,18 & 1,423 & Orta \\
\hline Kältürel etkinlikler çoktur & 380 & 1 & 5 & 2,43 & 1,345 & Desşuk \\
\hline Sağglık imkânlan iyidir & 380 & 1 & 5 & 2,84 & 1,356 & Orta \\
\hline Alışveriş imkânlan çoktur & 379 & 1 & 5 & 2,51 & 1,369 & Dusşak \\
\hline Sanayi gelişmiştir & 380 & 1 & 5 & 2,07 & 1,146 & Dūşâk \\
\hline Imkânlarn gelișmiștir & 380 & 1 & 5 & 2,17 & 1,133 & Düșak \\
\hline Tarihi açıdan zengindir & 380 & 1 & 5 & 3,28 & 1,384 & Orta \\
\hline Cografi konumu iyidir & 380 & 1 & 5 & 2,92 & 1,433 & Orta \\
\hline Valid N (listwise) & 377 & & & & & \\
\hline
\end{tabular}

* Imaj Algı Düzeyi: $1,0 \leq x<1,8$ (Oldukça Dủșük) $\quad 1,8 \leq x<2,6$ (Düșâk); $2,6 \leq x<3,4$ (Orta) ; $3,4 \leq x<$ 4,2 (Yuksek) : 4,2 $\leq x<5,0$ (Oldukça Yoksek)

Katılımcıların Siirt kentinin kent üstünlüğü konusunda düşük imaja sahip ifadeleri çoğunluktadır: "Sanatsal etkinlikleri çoktur", Sanayisi gelişmiştir", "İmkânları gelişmiştir", "Kültürel etkinlikler çoktur", "Planlı gelişmiştir", "Yeşil alan bakımından yeterlidir", "Konaklama imkânları iyidir", "Spor etkinlikleri yeterlidir", "Alışveriş imkânları çoktur" ve "Spor etkinlikleri yeterlidir" gibi konularda katılımcıların imaj algısı son derece düşüktür. Bu durum Siirt kentinin birçok açıdan öğrencilere çekici gelmediği ve kentin öğrencilerin sosyo-kültürel ihtiyaçlarını karşılayacak imkânlara sahip olmadığını göstermektedir.

Katılımcıların, Siirt kentinin soyut imaj unsurlarına yönelik algılarının ölçüldüğü Tablo 6'da en yüksek imaj algı düzeyi "Sakindir" ifadesine aittir. Kentin soyut imaj unsurlarından "Moderndir", "Gelişmiştir", "Kalabalıktır" düşük değere sahip olan ifadelerdir.

Tablo 6: Katlımcıların Siirt kentinin soyut imaj unsurlarına yönelik algiları.

Table 6: Participants' perception of abstract image elements of Siirt city.

\begin{tabular}{|l|c|c|c|c|c|}
\hline & Minimum & Maximum & Mean & Std.Deviation & Imaj Algı Duzeyi \\
\hline Sakindir & 1 & 5 & 4,23 & 1,162 & Oldukça Yüksek \\
Dışa dōnuktür & 1 & 5 & 2,90 & 1,383 & Orta \\
Guvenilirdir & 1 & 5 & 3,37 & 1,417 & Orta \\
Moderndir & 1 & 5 & 2,21 & 1,263 & Duş̧uk \\
Temizdir & 1 & 5 & 2,72 & 1,367 & Orta \\
Gelişmiștir & 1 & 5 & 2,14 & 1,190 & Duş̧uk \\
Ucuzdur & 1 & 5 & 2,78 & 1,485 & Orta \\
Kalabalıktır & 1 & 5 & 2,37 & 1,242 & Dușuk \\
\hline
\end{tabular}


Katılımcıların halk imajı algılarının genelde orta düzeyde olduğu görülmektedir (Tablo 7). Katlımcılar, "moderndir", "gelişmiştir" "kalabalıktır" ve "yenilikçidir" konularında Siirt halkını düşük düzeyde algılamaktadırlar.

Tablo 7: Katlımcıların Siirt kenti halkına yönelik imajları.

Table 7: Images of the participants towards the city of Siirt.

\begin{tabular}{|c|c|c|c|c|c|c|}
\hline & $\mathrm{N}$ & Minimum & Maximum & Mean & $\begin{array}{c}\text { Std. } \\
\text { Deviation }\end{array}$ & $\begin{array}{c}\text { Imaj Algi } \\
\text { Dözeyi }\end{array}$ \\
\hline Sakindir & 380 & 1 & 5 & 4,23 & 1,162 & $\begin{array}{c}\text { Oldukça } \\
\text { Yakssek }\end{array}$ \\
\hline Dıı̧a đōnūktür & 380 & 1 & 5 & 2,90 & 1,383 & Orta \\
\hline Gtvenilirdir & 380 & 1 & 5 & 3,37 & 1,417 & Orta \\
\hline Moderndir & 380 & 1 & 5 & 2,21 & 1,263 & Duşak \\
\hline Temizdir & 380 & 1 & 5 & 2,72 & 1,367 & Orta \\
\hline Gelişmiştir & 380 & 1 & 5 & 2,14 & 1,190 & Duşak \\
\hline Ucuzdur & 380 & 1 & 5 & 2,78 & 1,485 & Orta \\
\hline Kalabaliktur & 380 & 1 & 5 & 2,37 & 1,242 & Duşak \\
\hline Sakindir & 380 & 1 & 5 & 4,02 & 1,333 & Yaksek \\
\hline Dindardur & 380 & 1 & 5 & 3,89 & 1,349 & Yaksek \\
\hline Gelenekseldir & 379 & 1 & 5 & 3,98 & 1,275 & Yaiksek \\
\hline Sukseidur & 380 & 1 & 5 & 4,00 & 1,299 & Yoksek \\
\hline Samimidir & 380 & 1 & 5 & 3,31 & 1,454 & Orta \\
\hline Hoşgöruladär & 380 & 1 & 5 & 3,24 & 1,500 & Orta \\
\hline Sicakkanlidur & 380 & 1 & 5 & 3,21 & 1,507 & Orta \\
\hline Naziktir & 380 & 1 & 5 & 2,99 & 1,465 & Orta \\
\hline Yardimseverdir & 380 & 1 & 5 & 3,32 & 1,510 & Orta \\
\hline Cömertir & 380 & 1 & 5 & 3,09 & 1,487 & Orta \\
\hline Girişimcidir & 380 & 1 & 5 & 2,81 & 1,433 & Orta \\
\hline Calıskandır & 379 & 1 & 5 & 2,93 & 1,450 & Orta \\
\hline Därustûr & 380 & 1 & 5 & 2,93 & 1,471 & Orta \\
\hline Yenilikçidir & 380 & 1 & 5 & 2,43 & 1,381 & Dusşak \\
\hline Valid N (listwise) & 378 & & & & & \\
\hline
\end{tabular}

* Imaj Algı D0uzeyi: $1,0 \leq x<1,8$ (Oldukça Dụşak) $1,8 \leq x<2,6$ (Duşsuk);

$2,6 \leq x<3,4$ (Orta) ; $3,4 \leq x<4,2$ (Yüksek) $; 4,2 \leq x<5,0$ (Oldukça Yüksek)

Katılımcıların Siirtli olup olmaması durumuna göre Kent Soyut İmajı, Kent Halkı İmajı ve Kent Üst İmajı ölçeklerine verdikleri puanlar istatistiki önemli farklılık göstermiştir $(p<0.01)$ (Tablo 8).

Tablo 8: Katlımcıların Siirtli olup olmadığına göre Siirt kent imajı. Table 8: City image of participants by Siirt and Non-Siirt.

\begin{tabular}{|c|c|c|c|c|c|}
\hline & Minimum & Maximum & Mean & Std.Deviation & Imaj Algı Duzeyi \\
\hline Sakindir & 1 & 5 & 4,23 & 1,162 & Oldukça Yüksek \\
\hline Dışa dōnüktür & 1 & 5 & 2,90 & 1,383 & Orta \\
\hline Govenilirdir & 1 & 5 & 3,37 & 1,417 & Orta \\
\hline Moderndir & 1 & 5 & 2,21 & 1,263 & Duşsuk \\
\hline Temizdir & 1 & 5 & 2,72 & 1,367 & Orta \\
\hline Gelişmiștir & 1 & 5 & 2,14 & 1,190 & Duşukuk \\
\hline Ucuzdur & 1 & 5 & 2,78 & 1,485 & Orta \\
\hline Kalabalıktır & 1 & 5 & 2,37 & 1,242 & Dușưuk \\
\hline
\end{tabular}

Tablo 8 incelendiğinde cinsiyete göre oluşan grupların Siirt Kent İmajı ölçeklerinden aldıkları puanlar arasında istatistiksel bakımdan anlamlı bir farklılık olduğu görülmektedir. Siirtli olan öğrencilerin kentin memleketleri olmaları ve dolayısıyla aidiyet duygusu kent hakkında olumlu bir imaja sahip olmalarını sağlamıştir.
Öte yandan katlımcıların Siirt kenti hakkındaki görüşleri incelendiğinde, \%73,2'i üniversiteyi bitirdikten sonra Siirt'te yaşamayı düşünmemektedir (Tablo 9). Siirt'te yaşamayı düşünenlerin \%50'si Siirtli, \%50 ise Siirtli değildir. Siirt'te yaşamayı düşünmeyenlerin \%18'si Siirtli, \%88,9'u Siirtli değildir. Kaṫlımcıların \%31,3'ü kenti çok dilli kent olarak algılamaktadırlar. Bunu \%27,1 kenti dini kent imajı ile benimseyen öğrenciler takip etmektedir. Buna karşılık öğrencilerin \%4'ü kenti ticaret kenti olarak görmektedir (Tablo 9).

Tablo 9: Katlımcıların Siirt hakkındaki görüşleri

Table 9: Participants' views on Siirt.

\begin{tabular}{|c|c|c|c|}
\hline & & $\mathbf{F}$ & $\%$ \\
\hline \multirow{3}{*}{ Universiteden sonra da Sïrt'te yaşamayı dusșunebilirim. } & Evet & 100 & 26,3 \\
\hline & Hayır & 278 & 73,2 \\
\hline & Toplam & 380 & 100 \\
\hline \multirow{6}{*}{ Siirt sizce hangisidir? } & Ticaret & 16 & 4,2 \\
\hline & Egitim & 58 & 15,3 \\
\hline & Tarm & 84 & 22,1 \\
\hline & Dini & 103 & 27,1 \\
\hline & Cok dilli & 119 & 31,3 \\
\hline & Toplam & 380 & 100 \\
\hline \multirow{5}{*}{$\begin{array}{l}\text { Sïrtte 0̂niversite okuyan ögrencilerin kente katkıs1 } \\
\text { hangi yönlerdedir? }\end{array}$} & Ekonomik & 173 & 45,5 \\
\hline & Toplumsal & 67 & 17,7 \\
\hline & Bilimsel & 18 & 4,7 \\
\hline & Hepsi & 122 & 32,1 \\
\hline & Toplam & 380 & 100 \\
\hline \multirow{3}{*}{$\begin{array}{l}\text { Bu kentte üniversiteliler kalttirel yozlaşmaya neden } \\
\text { olmaktadır. }\end{array}$} & Evet & 155 & 40,8 \\
\hline & Hayır & 225 & 59,2 \\
\hline & Toplam & 380 & 100 \\
\hline \multirow{3}{*}{$\begin{array}{l}\text { Bu kentte üniversiteliler bölgesel kalknnmanin temel } \\
\text { unsurudur. }\end{array}$} & Evet & 282 & 74,2 \\
\hline & Hayir & 98 & 25,8 \\
\hline & Toplam & 380 & 100 \\
\hline
\end{tabular}

Anket sonunda katılımcılara "Siirt'in en sevdiğiniz ve en sevmediğiniz üç özelliğini yazınız" şeklinde iki soru sorulmuştur. Kattlımcılar kentin sevdikleri özellikleri arasında sakin, küçük, ulaşım imkânlarının kolay olması ve yemeklerinin lezzetli olması şeklinde bir sıralama yaparken; kentin sevmediğiniz özellikleri ile ilgili soruya halkın üniversite öğrencilerine karşı olumsuz tutumu, kız öğrencilere karşı rahatsız edici tavırlar, cimri olmaları, sıcakkanlı olmamaları, öğrencilere ürünleri olduğundan pahalı satmaları, insanların dışarıda çayhane önlerinde oturmaları, caddeleri işgal etmeleri, hoşgörüsüzlük, kabalık, kentin gelişmemiş ve sıkıcı olması şeklinde cevaplar vermişlerdir. Öğrencilerin rahatsızlık duydukları çayhaneler kentte oldukça yaygın şekilde bulunmakta ve caddelerin her iki tarafinda sıralanmışlardır. Dolayısıyla caddelerde rahatça hareket edilmemekte ve çayhaneler ciddi bir görüntü kirliliği yaratmaktadır.

\section{Sonuç}

Kentler doğal ve beşeri yönden farklılıklar göstermektedirler. Bir kenti diğerinden ayıran bütün bu farklılıklar onun kent imaj algısının oluşumunda etkendir. Kentlerin kötü imaj algısı sosyal, kültürel ve ekonomik anlamda çeşitli sorunlar doğurmaktadır. Kentlerin imaj algısının uygun gelişebilmesi bu alandaki sorunların giderilmesi ile mümkündür. Siirt gibi gelişme eğilimindeki kentlerin büyümesi doğru yönetilen bir kent imajı ile sağlanabilir. Dolayısıyla, kent imajının önemli bir planlama unsuru olarak ele alınması gerektirmektedir. Kenti paylaşanlar, kentin imajı güçlendikçe toplumsal duyarlılığın artacağı; yapılması düşünülen yatırımlarda nitelik ve uygunluk aranmaya başlanacağını bilmelidir. Bu nedenle kentin önemli paylaşanlarından biri olan öğrenciler üzerinde bu çalışma yapılmıştır. 
Söz konusu Siirt kent imajı konusunda, katılımcıların kent üstünlük imajı düşük, kent halkına yönelik ve kentin soyut imajına yönelik algı ise orta düzeydedir. Sanatsal ve kültürel etkinlikler, spor etkinlikleri, konaklama ve alışveriş imkânları açısından katlımcıların Siirt kent algısı düşüktür. Katılımcılar Siirt'i daha çok sakin, küçük, ulaşımı kolay ve yemekleri güzel yani kent mutfağı olan bir kent olarak görmektedirler. Katılımcıların kent halkıyla ilgili kanaatleri pek de iç açıcı değildir. Siirt halkını kaba, yobaz, hoşgörüsüz, cimri, öğrencilere bir malı veya hizmeti olduğundan daha pahalıya satmak vb. davranışlarla tanımlamaktadırlar. Kentin en işlek alanı olan Güres Caddesi'nin her iki tarafina sıralanan çayhanelerde uzun zaman geçiren şahısların varlığından üniversite öğrencileri -özellikle kız öğrenciler- ciddi rahatsızık duymaktadırlar. Katılımcılar kent halkının kendilerini benimsemediklerini, dolayısıyla kent ile bütünleşemediklerini belirtmişlerdir.

Birer cazibe merkezi olan üniversiteler şehre dışarıdan çok sayıda insanın gelmesine neden olmaktadır. Üniversiteye eğitim almak için gelen öğrencilerin kent ekonomisine katkısı çok önemli boyuttadır (Tösten vd., 2017; Dilmaç, 2017). Bunun yanında öğrencilerin kentin gelişimine sosyal ve kültürel anlamda da katkı sağladığı unutulmamalıdır. Günümüzde insan hareketliliği artmıştır. Dolayısıyla üniversite eğitimi alan bu öğrenciler gelecekte farklı bölge ve kentlerde iş, eğitim, tatil, gezi vb. amaçı aktivitelerde bulunacaklardır. Oluşturulacak doğru bir kent imajı ile Siirt kenti yetiştirdiği bu nitelikli nüfusu bağrında barındırabilir ya da Siirt kent imajının bu öğrenciler vasıtasıyla geniş bir yelpazede temsili sağlanabilir. Siirt kentini bir ürün olarak kabul edersek, bu ürüne ilişkin doğru bir imaj planlanmazsa, mutlaka onun bir şekilde gelişigüzel algılanacağı gözden kaçmamalıdır.

Kentten kopuk kampüs sistemi katlımcılar nezdinde kent imajının oluşunda dezavantajlı bir durum doğurmaktadır. Kentin uygun alanlarına dağılan doğru şekilde konumlandırılmış birkaç fakülteden meydana gelen butik kampüsler katılımcıların kenti daha çok kullanmaları ve benimsemelerini sağlayabilir.

Kent, sadece konut, işyeri, AVM'ler, park, eğlence ve dinlenme alanlarından oluşmayıp, aynı zamanda insan ve çevre arasındaki etkileşimin yaşandığı, sosyal, kültürel ve ekonomik faaliyetlerin yapıldığı bir mekândır. Kentler pazarlanmaya konu olan bir üründür. Bu ürünün kar amacı sağlaması uygun bir imaj ile doğru orantılıdır. Kentin paydaşları tarafindan kentin güçlü tarafi olarak görülen, kentin geleceğinde önemli bir etken olacağı açıkça ortaya konan Siirt Üniversitesi'nin yetiştirdiği öğrencilerin kent hakkındaki imajları oldukça önem arz etmektedir. Kentsel büyümede devamlılı̆ı̆n sağlanması, kentlerin hâlihazırdaki potansiyellerini dikkate alarak kentsel imajlarını korumaya bağIıdır. Kentler için birer kent konseyi oluşturulup, oluşturulacak eylem planları ile kent imajı takip edilmelidir. Kentte oluşan düşük imaj olgusu katılımcılar için daha fazla sosyo-kültürel etkinliklerin nitelik ve nicelik açısından artırılması ile bertaraf edilebilir. Unutulmamalıdır ki, olumlu bir kent imajı oluşturmak için bir çaba mevcut değilse, gerileme başlamış demektir.

\section{Kaynakça}

Ardel, A. (1944). Van Gölü Bölgesi'nin Coğrafyası. Beşinci Üniversite Haftası-Van. 241: 91-112. İstanbul Üniversitesi: İstanbul

Aliağaoğlu, A., Uğur, A. (2016). Şehir Coğrafyası, İstanbul: Nobel Akademik Yayıncilık.

Aliağaoğlu, A., Uzun, A. (2017). Üniversite Öğrencilerinin Şehir İmajlarına Yönelik Bir Araştırma: Balıkesir Üniversitesi Örneği, Afyon Kocatepe Üniversitesi Sosyal Bilimler Dergisi, Cilt 19(1), s.40, 3958.

Anholt, S. (2010). Places, İdentity, İmage and Reputation, Macmillan Publishers Limited, England.

Antholt, S. (2006). The Anholt-GMI City Brands Index: How The World Sees The World's Cities, Place Branding, Cilt:2(1), 18-31.

Ataöv, A., Osmay, S. (2007). Türkiye'de Kentsel Dönüşüme Yönetimsel Bir Yaklaşım, METU JFA, S: 24(2), s.57-82.

Cop, R., Akpınar, İ. (2014). Öğrencilerin Kentlerin Markalaşmasına Yönelik Algıları, Marmara Üniversitesi i.i..B. Dergisi, Cilt XXXVI, Sayı I, S, 69-88.

Demirel, M., (2014). Burdur Kent İmajı: Mehmet Akif Ersoy Üniversitesi Öğrencileri Üzerine Bir Alan Araştırması, Mehmet Akif Ersoy Üniversitesi Sosyal Bilimler Enstitüsü Dergisi, Cilt 6(10), s.231, 231241.

Dilmaç, E. (2017). Siirt Üniversitesi'nin Bölgesel Kalkınmadaki Rolü, Siirt Üniversitesi Sosyal Bilimler Enstitüsü İktisat Anabilim Dalı Yüksek Lisans Tezi, Siirt.

Gecikli, F. (2012). Kent İmajı Amasya Şehri Üzerine Bir Uygulama, Ankara: Fenomen Yayınları.

Güler, Y. B., Gürer, A. (2015). Kent Marka Bağlıı̆ı̆ına Yerel Katılım Eğiliminin Etkisini Belirlemeye Yönelik Bir Araştırma, İnsan ve Toplum Bilimleri Araşttrmaları Dergisi, 4(1) 64-82.

Gümüş, N. (2017). Kent Pazarlaması Bağlamında Üniversite Öğrencilerinin Şehre Yönelik Algılarının Belirlenmesi: Kastamonu Illinde Bir Araştirma, Pamukkale Üniversitesi Sosyal Bilimler Enstitüsü Dergisi, (26), 299-314.

İri, R., İnal, M.E., Türkmen, H.H. (2011). Kent Pazarlamasında Bilinirliğin Önemi: Niğde Yöresinin Bilinirliliğinin Ölçülmesine Yönelik Bir Araştırma", Niğde Üniversitesi i.i..B.F. Dergisi, Cilt. 4, Sayı. 1, 81-96.

Karadağ, A, Turut, H. (2013). Üniversite Öğrencilerinin Kentsel Çevre Algısı Üzerine Bir Araştırma: İzmir Örneği, Coğrafi Bilimler Dergisi, Cilt 11(1), 31-51.

Lynch, K. (1960). The Image of the City, The M.I.T. Press, London, s.110.

Özdemir, Ş., Karaca, Y. (2010). Üniversite Öğrencilerinin Kent İmajı Üzerindeki Etkisi: Afyonkarahisar'da Bir Araşttrma, Üçüncü Sektör Kooperatifçilik, Cilt 45(1), 25-39.

Özdemir, Ş., Karaca, Y. (2009). Kent Markası ve Marka İmajının Ölçümü: Afyonkarahisar Kenti İmajı Üzerine Bir Araştırma", Afyon Kocatepe Üniversitesi i.i.B.F. Dergisi, Cilt.11, Sayı. 2, 113-134.

Özgüç, N., Tümertekin, E. (2007). Beşeri Coğrafya: İnsan, Kültür, Mekân, İstanbul: Çantay Kitapevi.

Tösten, R., Anık, S., Kayan, M.S., (2017), Siirt Üniversitesi Öğrenci Profili ve Harcama Analizi, Siirt Üniversitesi Sosyal Bilimler Enstitüsü Dergisi, Sayı: 6-7, 41-58.

Türkan, O. (2017). Çankırı Şehrinde Üniversite Öğrencilerinin Kentsel Çevre Algısı, Uluslararası Sosyal Araşttrmalar Dergisi, Cilt: 10(53), 409-423.

Yavuzçehre, S.P. (2016). Üniversitelerin Kentlerine Etkileri: Denizli Pamukkale Üniversitesi Örneği, Süleyman Demirel Üniversitesi, İktisadi ve İdari Bilimler Fakültesi Dergisi, C.21(1), 235-250. 